\title{
A study on the cultivation of College Students' academic ability and critical thinking ability
}

\author{
LIU Yang \\ ${ }^{1}$ Qiqihar Medical University, Qiqihar 161006,China \\ aliuyang@126.com
}

Keywords: College students, English, academic ability, critical thinking

\begin{abstract}
In the academic and educational circles of our country, the value of critical thinking has been widely recognized by scholars. As a way of thinking, critical thinking is a kind of opinion or behavior. Use appropriate standards or specifications to make sound judgment. By analyzing the present situation and causes of College English teaching, it is proposed to improve the academic ability of academic English, and to explore effective ways and means to promote the development of students' critical thinking. Improve the academic literacy, as well as the cultivation of critical thinking ability, and provide some reference for the reform of English Teaching.
\end{abstract}

\section{Introduction}

In recent years, the reform of College English Teaching in our country has been carried on and deepened. The upcoming college English teaching guide makes it clear that college English Teaching. The course has the dual nature of humanity and tool. On the basis of improving general English comprehensive ability. Focus on cross-cultural communication English, academic English or professional English Teaching of the three major categories, to enhance students' awareness of cross-cultural communication and ability to enhance the comprehensive cultural literacy; Learn English for professional English or related work in the future, Enable students to acquire the ability to use English effectively in their studies. To meet the needs of national, social and personal development. From the above, we find that the trend of academic English teaching will be the focus of the reform of higher education and teaching. Through the study of English in a certain field, the students can grasp the discourse, genre characteristics and basic language communication strategies and skills, So as to improve students' academic communication and communication ability. Cultivate the ability to use English materials to discuss ideas and distinguish between facts and opinions. The cultivation of English thinking ability can make the students identify the authenticity of the information, select the key, and innovate in thinking. In order to survive and develop in the social life, critical thinking ability is one of the life skills and skills that students should focus on. Therefore, the academic English teaching system is facing unprecedented challenges, the demand and the voice of the critical thinking ability is stronger.

\section{Critical thinking and College English teaching}

In the late 20th century, the United States has been the cultivation of critical thinking as the teaching objectives, established as the mission of education, education reform has become an important part of the movement. Critical thinking is when you look at things, phenomena, or ideas, not blindly agree. But through their own thinking and observation to find the problems, and ultimately the formation of a logical proposition of innovative thinking ability. We believe that the logical proposition is the key to critical thinking. It is necessary to have the evidence or basis to support the argument, and supplemented by the language of refinement and accuracy. In the whole process of critical thinking, there are several aspects, such as the ability to discover problems, the ability of language organization and the ability of logical thinking. In the face of the acquired information, critical thinking can combine knowledge and coping strategies. Through the analysis and thinking of their own judgments and conclusions. Critical thinking is the core of criticism. However, it is not to 
negate the point of view, the final conclusion of the so-called critical perspective is not necessarily a negative point of view. The key point is to get the deep understanding and affirmation of the right things through the critical perspective; the purpose is to absorb the positive part of the information while abandoning the negative factors. And on this basis to analyze and innovate.

However, the main contradiction in the present situation of College English teaching, Reflected in the transformation of teaching ideas and the actual implementation of the, This kind of mutual restriction hinders the innovation of College English teaching and the cultivation of students' critical thinking ability, Many teachers are aware that the main body of the class should be student-centered, However, in the process of practice teaching, few teachers can really let go of the right”, Most college English teaching is teacher centered, Students in the classroom is still in the passive acceptance and absorption. The status of language skills, the establishment of thinking ability is more inclined to the same thinking. Students do not have too much authority to discuss, think and criticize, The construction of the traditional teaching mode and the way of thinking seriously hinder the critical thinking ability of students, teachers and teaching atmosphere What I say goes. Suppresses the student's main body of critical thinking habits. With the development of College English curriculum and teaching reform. Many colleges and universities have set up the structure and content of College English Curriculum. With the practical application of English as the guide, to cultivate students' English application ability as the key point. However, the cultivation of students' thinking ability, especially the ability of critical thinking, is seldom taken into account.

At present, China's College English teaching objectives, curriculum design and teaching content, etc. Lack of attention and attention to critical thinking teaching, the reasons for this situation are complex. Objectively speaking, on English Majors' English comprehensive ability is lower than that of their thinking ability, if the requirements and objectives of College English teaching are promoted to the level of critical thinking ability training. So most of the students will be able to listen, speak, read and write the language ability of the defects, And cannot achieve good teaching results, The majority of English teachers do not establish the critical thinking of classroom teaching. The traditional concept of the subject is deeply rooted, the main aim of the course is teaching, the necessity of cultivating students' critical thinking ability is limited. Moreover, many teachers have to improve their knowledge and ability of critical thinking teaching. It is impossible to combine the cultivation of critical thinking ability with the teaching practice. This subjective factor is the key problem of the critical thinking teaching in College English Teaching.

\section{The cultivation of critical thinking ability in academic English Teaching}

According to the national requirements for higher education, Colleges and universities should cultivate a large number of international talents with international vision, can participate in international affairs and international competition. The goal of College English teaching should not be limited to improve students' comprehensive ability of language application, humanistic quality, intercultural communicative competence, We should also pay attention to the teaching of general English (EGAP) and professional English (ESAP) Cultivating students' academic ability in English learning and research, Not only academic English skills, And focus on critical thinking ability as the core of academic literacy. Therefore, in the academic English teaching system, we should pay attention to the ways and Strategies of cultivating critical thinking ability from the aspects of teaching and so on.

We should establish the teaching concept of critical thinking. Due to the influence of Chinese traditional culture and thinking mode, College English Teaching in a period of time to pay attention to the basic knowledge of grammar teaching, And teachers lack the knowledge and ability of critical thinking teaching, It is not enough to pay attention to the cultivation of students' critical thinking ability. Students tend to focus on the absorption of knowledge in learning, the knowledge that teachers teach Correctness and authority, there is a lack of critical thinking. Therefore, both students and teachers should change the traditional ideas, Teachers should be guided by the idea of "learning 
by using”, through the course teaching based on Academic English. To promote the establishment of students' innovative thinking, thus abandoning the traditional concept of Education. Set up the concept of critical thinking quality education focusing on cultivating innovative spirit and practical ability.

The teaching mode of cultivating critical thinking ability, Colleges and universities in the development of College English teaching objectives, Students cannot simply remember the number of words, The mastery of grammatical accuracy and the speed of reading, Students should be encouraged to learn to question in the teaching process based on Academic English content, Good at finding and asking questions, and deep thinking and exploration, A logical and reasonable solution is obtained. In the course of teaching, students' English learning is no longer passive indoctrination and simply rely on book knowledge, But through the process of reflection and criticism to grasp the different ways of knowledge acquisition. The teacher can urge the students to deal with the task of judging and evaluating the reasons, help them improve the language skills required for the task, Create an environment that values critical thinking and encourages students to engage in critical discussions.

Focus on interdisciplinary and open knowledge for teaching content. The content of academic English teaching is just a carrier. Its purpose is to enable students to acquire language skills or academic exchanges in a particular field, so it should cover the general knowledge of interdisciplinary and professional knowledge related to science. In the teaching content, choose the concept of the division of University as the basis of the academic upgrading of teaching materials, or to the professional needs of the professional development oriented teaching materials. The combination of critical thinking teaching and regular English Classroom Teaching. Focus on training students to acquire, analyze, integrate and judge the content information. Develop critical reading and thinking skills. Moreover, academic English teaching can help students to improve their language skills and improve their English proficiency, Access to professional related cutting-edge information, Encourage active participation in discussions, speculative innovation and collaborative inquiry, In order to improve the academic English ability and cultivate academic attainments.

Design English courses with logical style. As the leader of classroom design, teachers need to have the ability of curriculum design, In order to inspire students to think. Academic English classroom is no longer a simple explanation of the knowledge. It is also necessary to guide the students through the identity of the guide. In the teaching practice, we should start from the discourse theme or background, Pay attention to the meaning of content, the purpose of writing, the use of artistic conception, etc., let the students spontaneously question, the teacher through the logical explanation and the analysis lets the student to the question which has a kind of enlightenment feeling. Finally, the critical thinking methods, such as comprehension, analysis and evaluation, etc. Ability to train students to solve problems, promoting the cultivation of students' critical thinking ability

\section{Conclusion}

To sum up, the academic English teaching system is bound to subvert the traditional college English teaching philosophy, objectives, models and content, etc., Not only to meet the needs of students to explore knowledge, But also to instill in students the true academic value. Arouse the desire to seek knowledge, Skills for training assessment and critical evaluation. As an educator, students should be able to improve their academic English communication skills, as well as academic literacy, critical thinking ability and the important task of training. Critical thinking ability is not only a learning, thinking ability, It is also a kind of personality temperament with modern humanistic spirit, College English teachers should have the courage to reform, Cultivating students' critical thinking ability in English language teaching, Not only can promote the study of language itself, Can help students in the increasingly diversified information era of efficient thinking, rational analysis, Finally make the right choice 


\section{Acknowledgements}

Scientific Research Program on Higher Education in "the 13th Five-Year Plan" of Heilongjiang Association of Higher Education (No.: 16G285).

\section{References}

[1] Zhang P. On how to cultivate College-English learners 'ability of critical thinking[J]. Journal of Zhejiang University of Science \& Technology, 2016.

[2] Pearson C V. Barrier to Success: Community College Students Critical Thinking Skills.[J]. Academic Achievement, 2012:10.

[3] Facione P A. The California Critical Thinking Skills Test--College Level. Technical Report \#2. Factors Predictive of CT Skills.[J]. 1989:23.

[4] Ling X U. College English Classes and the Cultivation of College Students' Critical Thinking Ability[J]. Journal of Changchun Normal University, 2016.

[5] YAN Jiao-lan. The Cultivation of Students' Critical Thinking Ability in College English Teaching[J]. Theory and Practice of Education, 2014.

[6] Facione P A. The California Critical Thinking Skills Test--College Level. Technical Report \#1. Experimental Validation and Content Validity.[J]. Cognitive Tests, 2013:21.

[7] Moon J L. Honors and High-Ability Students: Factors That Predict Academic Efficacy, Critical Thinking Skills, and Academic Goals.[J]. Proquest Llc, 2012:169.

[8] Nicole, Hansen, Salas, et al. Relation Between Type of Academic Institution of Origin and Development of Critical Thinking Abilities in College Students[J]. 美 中教育评论:b, 2014(11):834-838.

[9] Prendergast D L. Influences of college environments and the development of critical thinking skills in college students.[J]. Dissertation Abstracts International, 2011, 59(4-a).

Colleges A S F C C, Sacramento. Critical Thinking Skills in the College Curriculum.[J]. 2013, 25(4):21.

[10] Shim W, Walczak K. The Impact of Faculty Teaching Practices on the Development of Students' Critical Thinking Skills.[J]. International Journal of Teaching \& Learning in Higher Education, 2011, 24:16-30.

[11] Lehmann I J. Critical Thinking Ability, Attitudes, and Values Among College Students[J]. Journal of Teacher Education, 1962, 13(4):376-385.

[12] James H. McMillan. Enhancing college students' critical thinking: A review of studies[J]. Research in Higher Education, 1987, 26(1):3-29. 